\title{
Characterization and Comparative Analysis of Corrosion Resistance of 4 High Manganese Steels Models in Aqueous Solution of $\mathrm{NaCl}$
}

\author{
Mauro Andres Cerra Florez ${ }^{a} \mathbb{D}^{\mathbb{D}}$, Marcos Natan da Silva Lima ${ }^{a}$, Walney Silva Araújo \\ Marcelo José Gomes da Silva \\ ${ }^{a}$ Departamento de Engenharia Metalúrgica e de Materiais, Universidade Federal do Ceara-UFC, \\ Fortaleza, CE, Brasil
}

Received: April 08, 2019; Revised: August 27, 2019; Accepted: October 10, 2019

\begin{abstract}
The liquefied natural gas volumes that currently need to be stored and/or transported require engineering to consistently develop materials that combine high mechanical strength and low manufacturing costs. The present work brings the study of four models of high manganese steels (noncommercials), to demonstrate the feasibility of being used in the petrochemical industry. The tests contemplate the characterization (composition, phase diagram, metallography, EBSD, microhardness), corrosion resistance in $\mathrm{NaCl}$ solution (Open Circuit Potential, Linear Polarization) and characterization of corrosion products (EDS, SEM, Raman Spectroscopy). The obtained results showed a relationship between the increases of the manganese content with: formation of twins that help their hardening, as well as the decrease of their corrosion resistance; the steel with less amount of this element had a more noble behavior. Quantities of chromium, silicon and aluminum in these steels could not contain the high dissolution of manganese, which caused low stability of the formed oxides that allows the electrolyte ions to reach the metal surface, accelerating the dissolution process.
\end{abstract}

Keywords: High manganese steel, Characterization, EBSD, Corrosion. Raman.

\section{Introduction}

Since the industry began the extraction of natural gas, it was necessary to develop materials that could withstand the cryogenic fluids storage and transport conditions. Initially, the materials had difficulty maintaining the same mechanical properties at temperatures well below $0{ }^{\circ} \mathrm{C}$. The ductile-brittle transition phenomenon, which is the change in mechanical properties related to ductility as the temperature decreases, has been much studied. The use of different alloying elements helps in the improvement of mechanical and chemical properties, and in the reduction of costs in the production of these steels ${ }^{1}$.

In general, the alloys used in the manufacture of liquefied natural gas tanks require high mechanical strength so that the thickness of the tank wall is minimized, as it is necessary that these alloys have high toughness at low temperatures. High manganese austenitic steels have been shown to be promising materials for applications where high mechanical strength is required at cryogenic temperatures and they have become attractive due to their low cost and to the stabilizing element of austenite, the phase that maintains the mechanical properties required for low temperatures ${ }^{2,3}$. The excellent mechanical properties of steels with high manganese content have been the subject of several studies. It was concluded that the mechanical resistance is due to the presence of twins and ductility as a result of the remaining austenite. The twins are modifications of the crystallographic orientation planes within the grains and they act as a barrier

* e-mail: mauro.cerra@gmail.com to the discordances movement ${ }^{4}$. This effect is called TWIP (Twinning Induced Plasticity).

There are some studies on the electrochemical polarization behavior of Fe-Mn-Al alloys. Some authors have reported that these steels do not passivate in aqueous solutions of $3.5 \% \mathrm{NaCl}, 10 \% \mathrm{HCl}$ or $10 \% \mathrm{HNO}_{3}$ and are susceptible to pitting corrosion, but this depends on the alloying elements and their amounts ${ }^{5}$. It has also been reported that increasing the content of manganese above $25 \%$ decreases the corrosion resistance of the alloy in aqueous solutions ${ }^{6}$.

In this work, samples of four high manganese steel models were used - which were analyzed to obtain their chemical compositions. A thermodynamic simulation was performed in Thermo-Calc ${ }^{\circledR}$ software and, with the diagrams obtained; it was possible to determine the temperature at which the heat treatments are to be performed to obtain the desired microstructure. After the thermal treatments, the study of the microstructure was carried out to confirm the present phases and to identify its influence on the mechanical properties and the resistance to corrosion. Microhardness tests were also performed to study the relationship between the chemical composition and the microstructure in the mechanical properties of these steels. To study the corrosion resistance of high manganese steels, Open Circuit Potential (OCP) and Linear Polarization techniques were used. The results showed the curves and the corrosion potential, and the corrosion resistances of these steels were determined. An aqueous solution of $\mathrm{NaCl}$ was used because the storage tanks are located in ships or in regions near the sea, where the metal is exposed to the effects of $\mathrm{Cl}$ ions present in 
the marine atmosphere. In addition to the corrosion tests, the surfaces of the samples were characterized to observe corrosion products by SEM, EDS and Raman spectroscopy.

\section{Experimental}

High manganese steels were manufactured with the following carbon and manganese specifications: $28 \% \mathrm{Mn}-$ $0.2 \%$ C, $26 \% \mathrm{Mn}-0.3 \%$ C, $23 \% \mathrm{Mn}-0.45 \% \mathrm{C}$, and $20 \%$ $\mathrm{Mn}-0.6 \% \mathrm{C}$, to avoid the presence of epsilon martensite in the microstructure of the steels. Samples of the steels were cut, sanded, washed with ethanol and dried with a hot air jet, and the chemical composition was determined on the X-ray Rigaku fluorescence spectrometer model ZSX Mini II. With the preparation of the chemical compositions, it was possible to carry out simulations in the Thermo-Calc ${ }^{\mathbb{B}}$ program, database TCFE6, which allows the elaboration of phase diagrams and evaluation of thermodynamic data. The steels sampleswere heat treated at $1150{ }^{\circ} \mathrm{C}$ for 1 hour, and then cooled in water. The previous treatment was done to obtain the typical microstructure in these steels that is used in the industry.

For the metallographic preparation, the samples were sanded with silicon carbide sieves from 100 to 2500 , followed by ethanol washing to degrease and hot air jet to dry the surface, according to ASTM E3 (Preparation of Metallographic Specimens). After that, the polish was adjusted with alumina of 1 micron and then the electrolytic polishing was done in 10 seconds using a solution of $50 \%$ glycerol $+25 \%$ ethyl alcohol $+25 \%$ phosphoric acid in a cell with platinum counter electrode, $5 \mathrm{~A}$ current and $18 \mathrm{~V}$ voltage for $8^{7}$. To reveal the microstructure, a solution of $40 \%$ nitric acid $+60 \%$ distilled water was used for 20 seconds ${ }^{7}$. Microstructural analysis was performed using the Zeiss ${ }^{\circledR}$ optical microscope model AX10.It has been applied the EBSD sample preparation for the tests, the same way as in the metallography test, with a difference in polishing, which was made with alumina 1 micron and 0.5 for steels with $20 \%$ to $22 \%$ manganese; in the case of $26 \%$ and $28 \%$ manganese steels, 1 micron alumina was used and then the electrolytic polishing was performed for 60 seconds using a solution of $50 \%$ glycerol $+25 \%$ ethyl alcohol $+25 \%$ phosphoric acid ${ }^{7}$. Microstructural analysis was performed on Philips Scanning Electron Microscope XL-30, EBSD OXFORD / HKL Channel
5.The microhardness measurements were performed on the Vickers scale in the Shimadzu digital microdurometer model HMV, with a load of 2.942N (HV3); all samples were sanded and polished with diamond paste prior to assay, and fifteen measurements were taken in each sample, according to ASTM E92 ${ }^{8}$.

Electrochemical measurements were performed on the Metrohm $^{\circledR}$ Autolab PGSTAT 302 N potentiostat/galvanostat, controlled by the NOVA ${ }^{\circledR}$ program. Open Circuit Potential (OCP) and Linear Polarization tests were performed using a standard three-electrode cell: $\mathrm{Ag}$ (s) / $\mathrm{AgCl}$ (s) / Cl- (aq) (saturated $\mathrm{KCl}$ ) as the reference electrode, working electrode were the steel samples and the counter electrode was a platinum plate with a geometric area of approximately 130 $\mathrm{mm}^{2}$. The tests were done at room temperature and inside a Faraday cage. OCP tests were performed for 1 hour; the linear polarization curves were obtained in a potential range of +200 to $-100 \mathrm{mV}$ around the Open Circuit Potential, with a scanning rate of $1 \mathrm{mV} / \mathrm{s}$, ending in $1 \mathrm{~mA}$ of current ${ }^{9}$, in $0.1 \mathrm{M} \mathrm{NaCl}$ solution.

After the corrosion tests, images were obtained for the visualization of morphology details of the corrosion products by the TEGAN ${ }^{\circledR}$ VEGA XMU scanning electron microscope (SEM) and X-ray energy scattering (EDS) spectroscopy, using the Esprit software 1.8; also using Raman spectroscopy with the WITec alpha300 spectrometer.

\section{Results and Discussion}

\subsection{Chemical composition}

Table 1 shows the chemical composition of high manganese steels obtained by X-ray fluorescence, in which it is observed that the quantities of carbon and manganese were approximated to those requested; also aluminum, silicon and chromium contents were found, and these contents decrease as the manganese content increases. Small amounts of other elements have been found and this is due to the manufacturing process. The carbon-manganese ratio in the chemical composition was used to avoid precipitation of epsilon martensite $(\varepsilon)$ and to ensure a completely austenitic matrix; with the help of the Schumann Fe-C-Mn phase stability diagram shown in Figure 1, it is possible to locate the compositions of these steels in the stability area of the austenite phase ${ }^{10}$.

Table 1. Chemical composition of high manganese steel models obtained by X-ray fluorescence. Source: author.

\begin{tabular}{lcccccccccccc}
\hline \multicolumn{2}{l}{ Chemical composition of steels $(\mathbf{w t} \%)$} \\
\hline $20-\mathrm{Mn}$ & $\mathbf{F e}$ & $\mathbf{M n}$ & $\mathbf{A l}$ & $\mathbf{S i}$ & $\mathbf{C}$ & $\mathbf{C r}$ & $\mathbf{N i}$ & $\mathbf{C u}$ & $\mathbf{M o}$ & $\mathbf{P}$ & $\mathbf{S}$ \\
$22-\mathrm{Mn}$ & Bal. & 19,73 & 3,65 & 2,8 & 0,62 & 0,54 & 0,24 & 0,17 & 0,06 & - & - \\
$26-\mathrm{Mn}$ & Bal. & 22,22 & 3,39 & 2,51 & 0,53 & 0,48 & 0,26 & 0,2 & 0,05 & 0,03 & - \\
$28-\mathrm{Mn}$ & Bal. & 24,98 & 1,05 & 1,51 & 0,32 & 0,29 & 0,16 & 0,12 & - & 0,04 & 0,02 \\
\hline
\end{tabular}




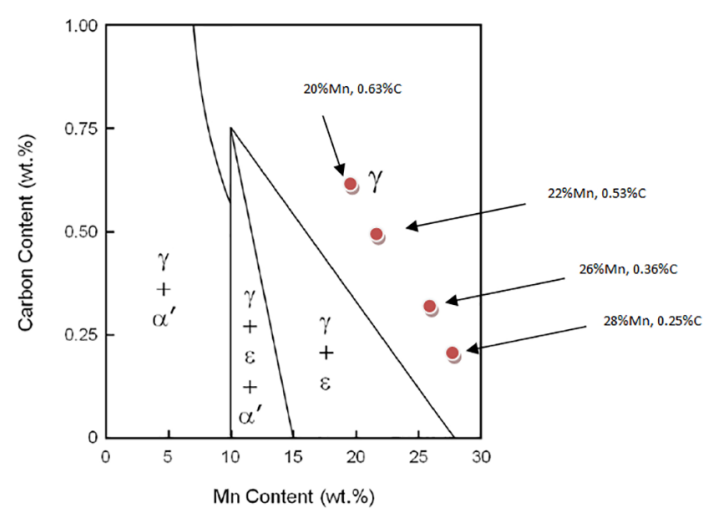

Figure 1.Fe-C-Mn phase stability diagram with the points indicating the composition of the steels studied. Source: Schumann ${ }^{10}$.

\subsection{Thermodynamic diagrams}

With the chemical composition, the mass fraction diagrams of the steels were constructed in Thermo-Calc ${ }^{\mathbb{B}}$ software. These diagrams show the amounts of the phases and serve as guides for determining the temperatures at which thermal treatments are to be performed to obtain the desired microstructure. Figure 2 shows the mass fraction diagram of $20 \%$ manganese steel, where it is possible to see that the austenite forms from the liquid at a temperature of approximately $1350^{\circ} \mathrm{C}$, remaining as the only phase present from $1270{ }^{\circ} \mathrm{C}$ to $770{ }^{\circ} \mathrm{C}$. Below $770{ }^{\circ} \mathrm{C}$, the precipitation of the $\mathrm{M} 7 \mathrm{C} 3$ carbide is observed in small amounts. At temperatures below $670{ }^{\circ} \mathrm{C}$, the ferrite (BCC) is formed, and when the temperature decreases, it is observed the increase of ferrite and the decrease of austenite. Below $460{ }^{\circ} \mathrm{C}$, the formation of $\mathrm{M} 23 \mathrm{C} 6$ carbide is observed, and the $\mathrm{M} 7 \mathrm{C} 3$ carbide is seen to disappear.

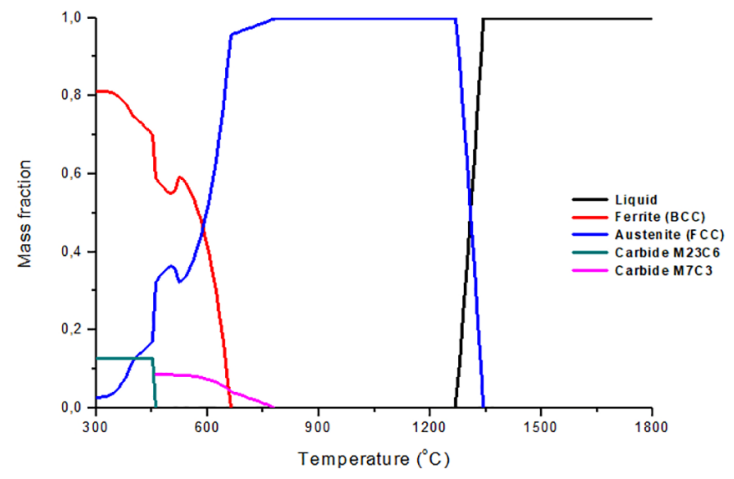

Figure 2. Mass fraction diagram of the $20 \%$ manganese steel. Source: author

The mass fraction diagram of the $22 \%$ manganese steel is shown in Figure 3, and it is observed that at a temperature below $1350{ }^{\circ} \mathrm{C}$ austenite is formed from the liquid, and between $670{ }^{\circ} \mathrm{C}$ and $1270{ }^{\circ} \mathrm{C}$ it is the only phase. Below $670{ }^{\circ} \mathrm{C}$ is the precipitation of the $\mathrm{M} 7 \mathrm{C} 3$ carbide in small amounts. At temperature below $610^{\circ} \mathrm{C}$, the ferrite phase
(BCC) is formed and it increases its proportion as the amount of austenite decreases because of the reduction in temperature. Below $460{ }^{\circ} \mathrm{C}$, precipitation of $\mathrm{M} 23 \mathrm{C} 6$ carbide occurs and $\mathrm{M} 7 \mathrm{C} 3$ carbide disappears. The diagram of this steel is similar to that of the $20 \%$ manganese steel, with the difference that the formation or precipitation temperatures of the phases are relatively smaller.

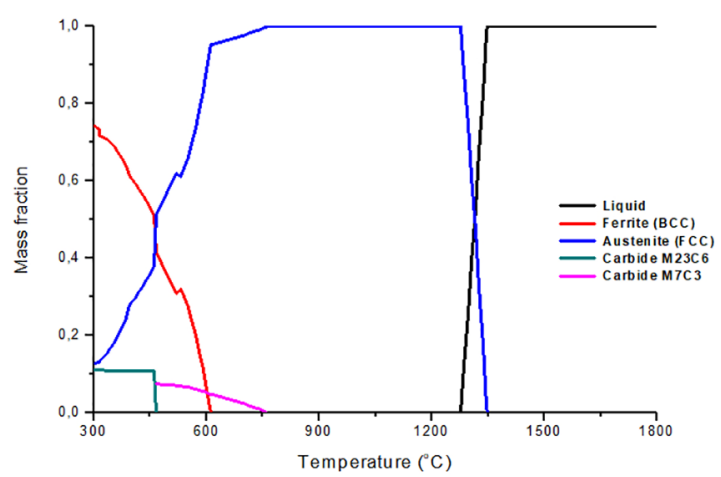

Figure 3. Mass fraction diagram of the $22 \%$ manganese steel. Source: author

Figure 4 shows the mass fraction diagram of the $26 \%$ manganese steel. Austenite forms at a temperature below $1370{ }^{\circ} \mathrm{C}$, from the liquid, and it is stable with $100 \%$ of the steel composition between $670{ }^{\circ} \mathrm{C}$ and $1300{ }^{\circ} \mathrm{C}$. The formation of the M7C 3 carbide happens between $480{ }^{\circ} \mathrm{C}$ and $670{ }^{\circ} \mathrm{C}$, but in less than $10 \%$ of the phases. The ferrite phase (BCC) forms below $510{ }^{\circ} \mathrm{C}$ and it increases as the temperature decreases. Below $480{ }^{\circ} \mathrm{C}$, the $\mathrm{M} 23 \mathrm{C} 6$ carbide is formed and the $\mathrm{M} 7 \mathrm{C} 3$ carbide is discarded.

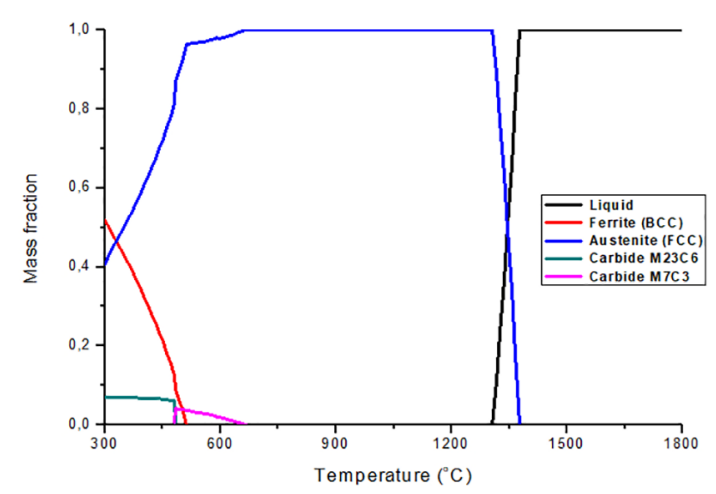

Figure 4. Mass fraction diagram of the $26 \%$ manganese steel. Source: author

The mass fraction diagram of the $28 \%$ manganese steel is shown in Figure 5, where it can be observed that at a temperature below $1350{ }^{\circ} \mathrm{C}$ austenite (FCC) is formed from the liquid, and remains as a single phase between 645 ${ }^{\circ} \mathrm{C}$ and $1290^{\circ} \mathrm{C}$. The $\mathrm{M} 7 \mathrm{C} 3$ carbide is precipitated at 580 ${ }^{\circ} \mathrm{C}$ and $645^{\circ} \mathrm{C}$ in small amounts. Below $580^{\circ} \mathrm{C}$ the carbide $\mathrm{M} 7 \mathrm{C} 3$ is no longer available and the carbide $\mathrm{M} 23 \mathrm{C} 6$ is formed in amounts of less than $10 \%$. The ferrite phase 
(BCC) forms below $460^{\circ} \mathrm{C}$, and it increases in quantity as the temperature drops.

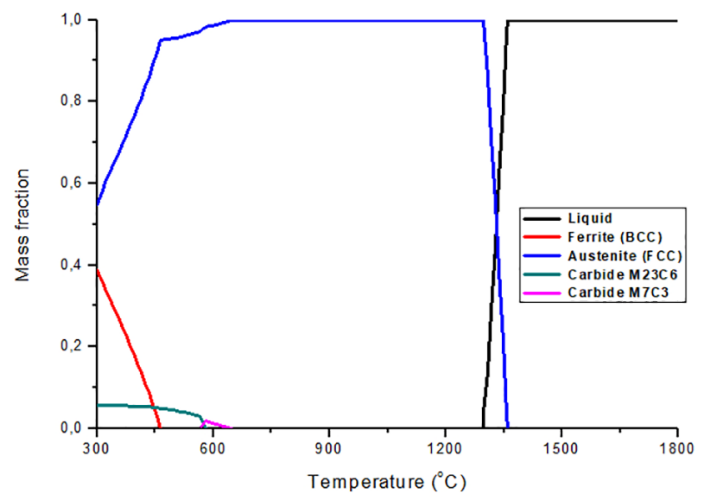

Figure 5. Mass fraction diagram of the $28 \%$ manganese steel. Source: author

In the analysis of the diagrams, the relationship between the increases in the content of manganese, together with the decrease of the carbon in the steel, with the stability of the austenite phase, the temperature range where austenite is the only stable phase became larger as it increased the content of manganese. Another important effect was the decrease of the formation temperatureof the ferrite and the precipitation of carbides. This shows the austenitic character of the manganese element in this type of steels, as mentioned by Zambrano et al. ${ }^{11}$.

\subsection{Microstructure}

Figure 6 shows images of the steels microstructures: a) $20 \%$ manganese, b) $22 \%$ manganese, c) $26 \%$ manganese and d) $28 \%$ manganese. In each of the images, it is possible to see equiaxial austenitic grains and the presence of twins inside the grains. The twins are identified as narrow subgrains, with straight and parallel edges, which divide the austenite grains $^{4}$. It is also important to mention the presence of porosity due to the electrolytic polishing process that was necessary to observe the constituents of the steel. It is possible to observe that there is a larger number of twins in the $26 \%$ and $28 \%$ manganese steels, due to the increase in the content of manganese in TWIP steels - the greater amount of this element has a direct influence on the stacking fault energy (SFE), which produces the formation of more twins instead of other phases such as martensite $3,4,12$.

By comparing the phases found in the microstructure with the phases described in the simulated thermodynamic diagrams in the Thermo-Calc ${ }^{\circledR}$ software, it is possible to say that the phases coincided, that the temperature of $1150^{\circ} \mathrm{C}$ chosen to make the heat treatment was adequate, and a completely austenitic microstructure was obtained.

\subsection{EBSD}

The EBSD technique was used for identification and quantification of the present phases, as well as to know the crystallographic orientations of the grains. Figure 7 shows the identification maps of preset phases in manganese steels: a) $20 \%$, b) $22 \%$, c) $26 \%$ and d) $28 \%$. As shown in literature, the steels with high levels of manganese are composed of austenite; in the diagram this phase is identified by the red color, this microstructure is $\mathrm{FCC}(\gamma)$ and it had $99 \%$ indexation in the four steels. The austenitic matrix is mainly due to the manganese and carbon contents - these elements decrease the temperature of transformation of the austenite into ferrite (as shown in the thermodynamic diagrams) and thus, with the help of thermal treatments, it is possible to have austenite at room temperature. It is also possible to observe a slight difference between the grain sizes of the samples with higher manganese contents; apparently, they presented larger grains (and they had the same thermal treatment time). In some images, blue dots were found, which appear to be indexing regions of the software that did not find the martensitic phase.

Figure 8 shows the inverse polar figures (IPF) of the austenitic grains, corresponding to the $20 \%, 22 \%, 26 \%$ and $28 \%$ manganese steels in the letters a, b, c and d, respectively. The inverse polar figures show the direction of the crystal using colors according to the triangle of the unit. It can be observed that the grains show a random crystallographic orientation. All steels show the characteristics of a typical TWIP steel microstructure, i.e. equiaxed grains, some of which contain one or two twins cutting the grain ${ }^{12}$

\subsection{Microhardness}

The microhardness of each of the steels was measured after solubilization heat treatment; the average of Vickers microhardness measurements is presented in Figure 9. The measurements in each sample showed relatively close values, which confirms the uniformity of the austenitic microstructure in these steels. It is important to remember that, in order to avoid the formation of deleterious phases in these steels, the manganese content has been increased and the carbon content has decreased, a consequence of which is the hardness reduction with the low carbon content (and increase of the manganese).

The high manganese steels have, within their microstructure, the twins. These twins constitute modifications of the crystallographic orientation planes, improving their mechanical properties due to the mechanism of hardening by twinning ${ }^{13}$. The higher content of carbon improves the hardness due to the interstitial character of this element, which acts as a barrier to the discordance movement and that under special conditions helps the hardening by deformation, that is, the transformation of austenite into martensite as a response to deformation ${ }^{3}$.

The phenomena of hardening by deformation and hardening by twinning make these steels promising raw materials for manufacturing automotive parts, components that can be subjected to impact, and also containers that work at high pressures and low temperatures, such as those used to store liquefied natural gas ${ }^{3}$. 

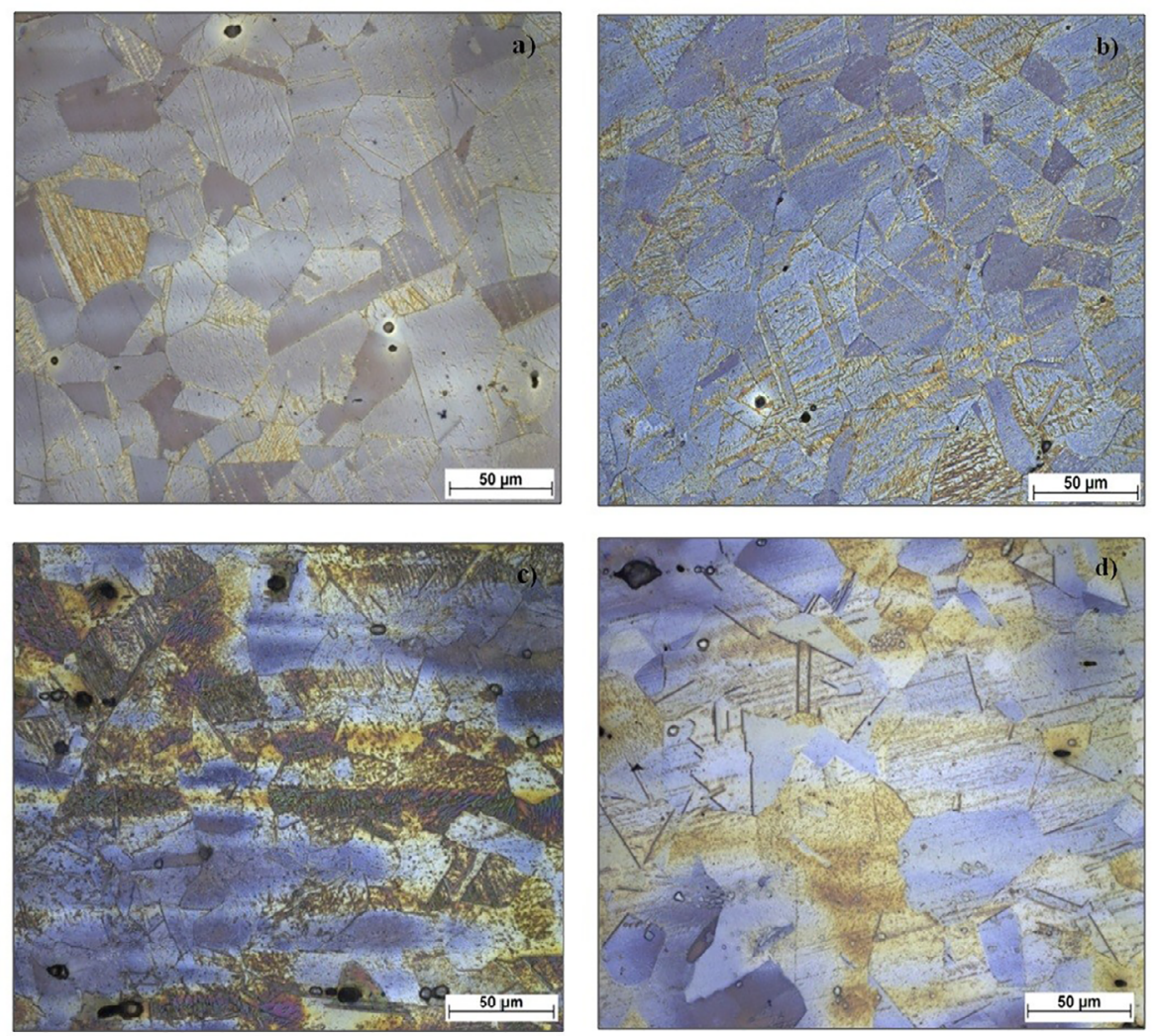

Figure 6. Microstructures of manganese steels: a) 20\% manganese, b) $22 \%$ manganese, c) $26 \%$ manganese and d) $28 \%$ manganese. Source: author.
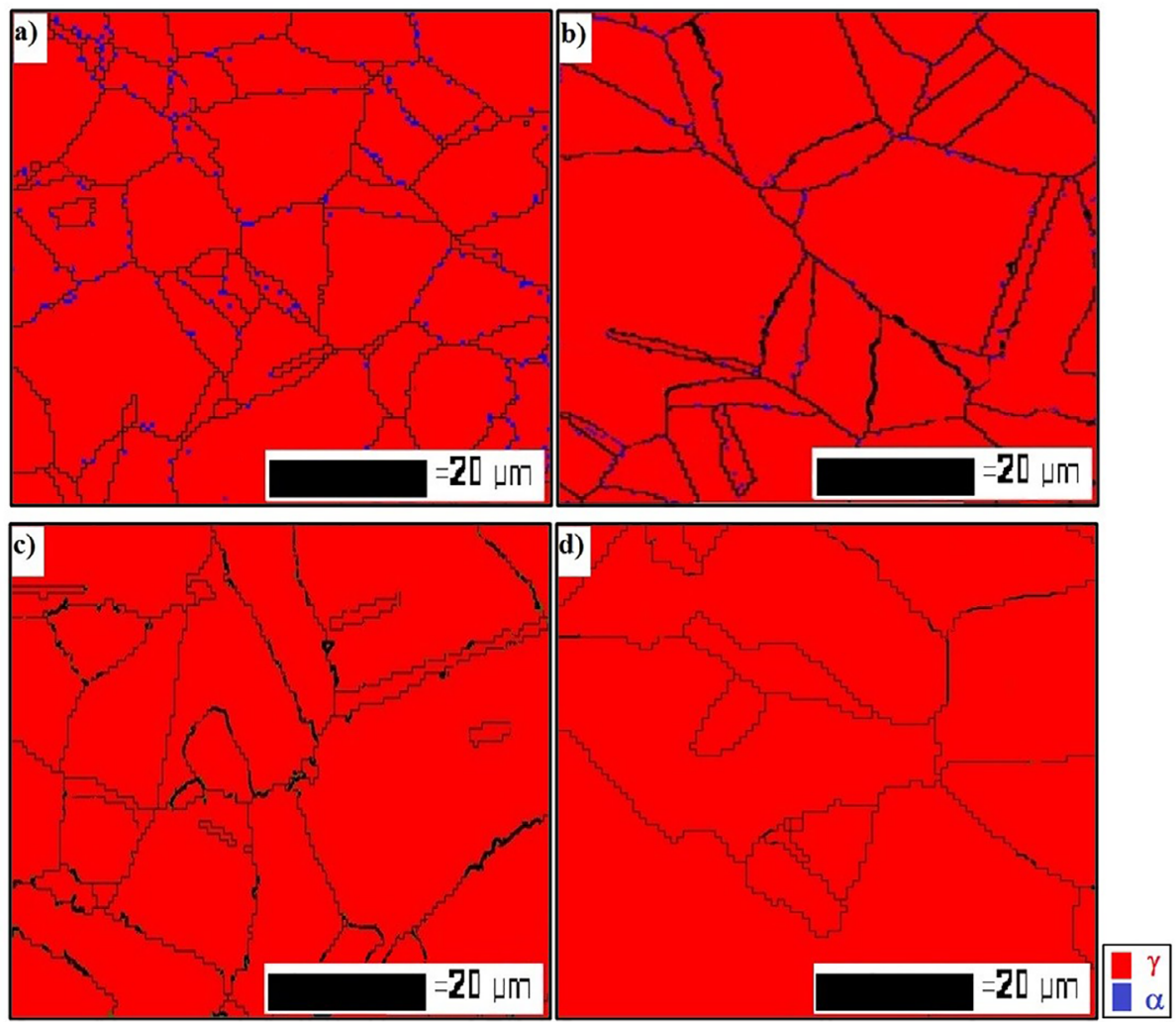

Figure 7. EBSD maps of hot rolled samples with $80 \%$ reduction and then solubilized. Increase by $500 \times$. a) $20 \%$ manganese, b) $22 \%$ manganese, c) $26 \%$ manganese and d) $28 \%$ manganese. Source: author 

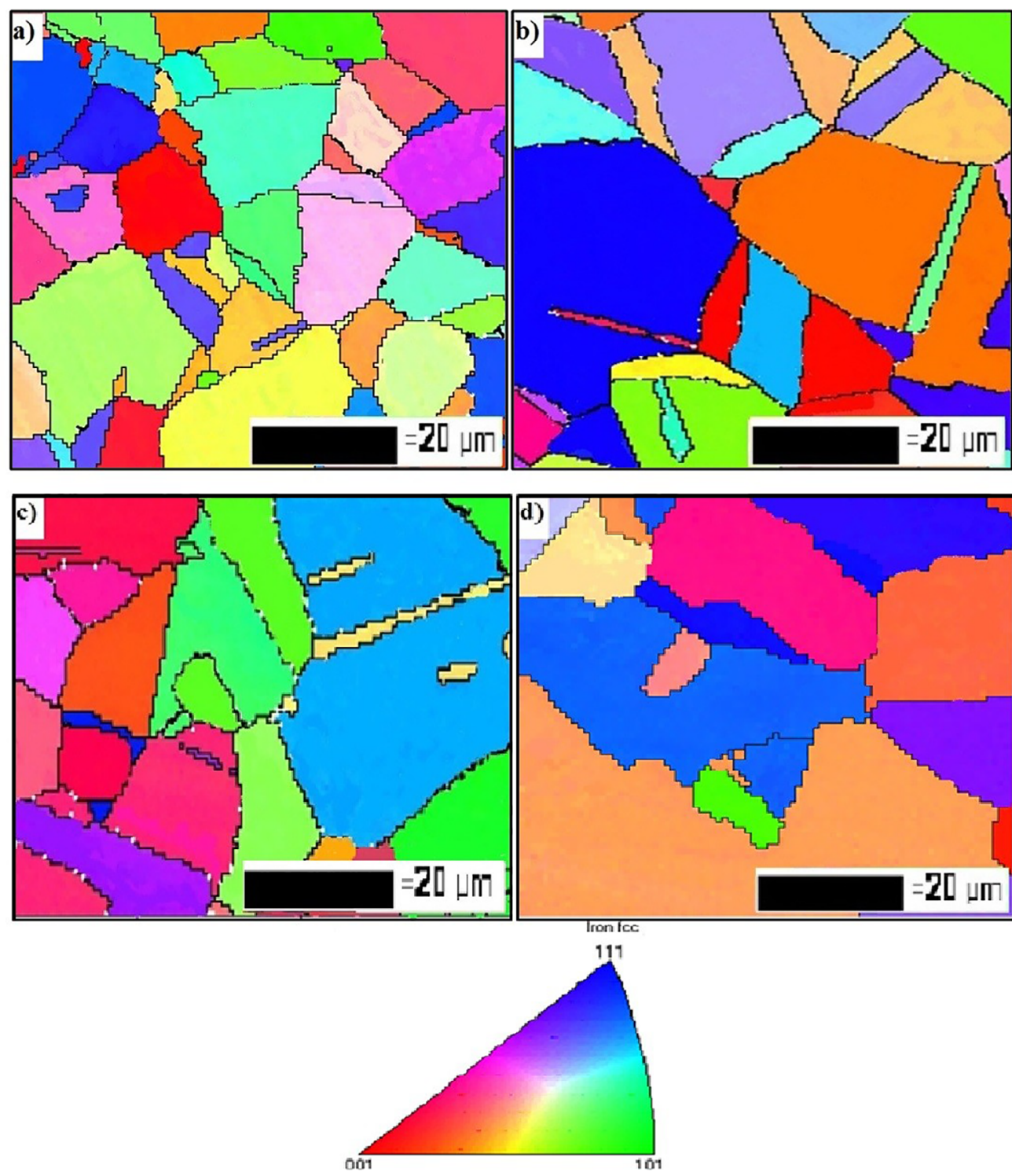

Figure 8. Inverse pole figures of hot rolled samples, with $80 \%$ reduction and then solubilized. Increase by $500 \times$. a) $20 \%$ manganese, b) $22 \%$ manganese, c) $26 \%$ manganese and d) $28 \%$ manganese. Source: author.

\section{6 Corrosion Tests}

In Figure 10, we observe the OCP and linear polarization

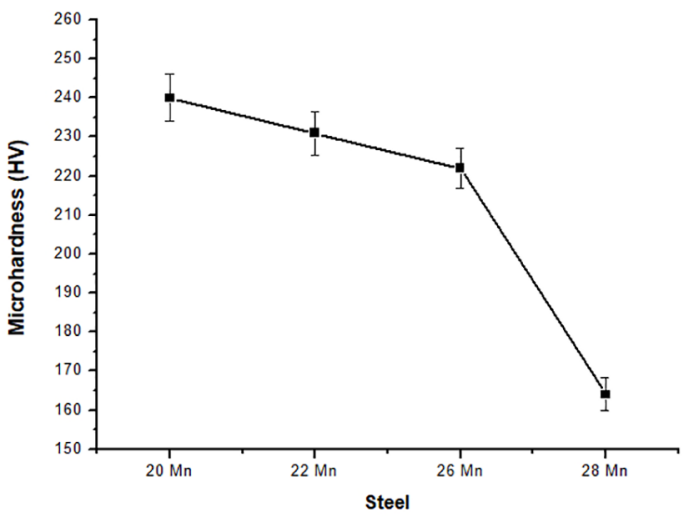

Figure 9. Microhardness of high manganese steels. Source: author. curves, and it is appreciated that none of the steels presented passive behavior as found in the work of Hamada et al. ${ }^{5}$. In general, it can be said that, with the increase of the manganese content, the resistance to corrosion decreases. In the OCP curves, it is observed how the amount of manganese leads the curves to more negative potentials, showing in $20 \%$ manganese steel a more noble behavior. The curve of the $20 \%$ manganese steel had a significant decrease and, after a while, rose to less negative powers; this is due to the electrochemical interactions between the metal surface and the electrolyte. In the other steels, it had initial variations and after a while it stabilized. The most important characteristic of these results is to see how the increase of manganese in the steel has a relation with the decrease in the corrosion potential. 

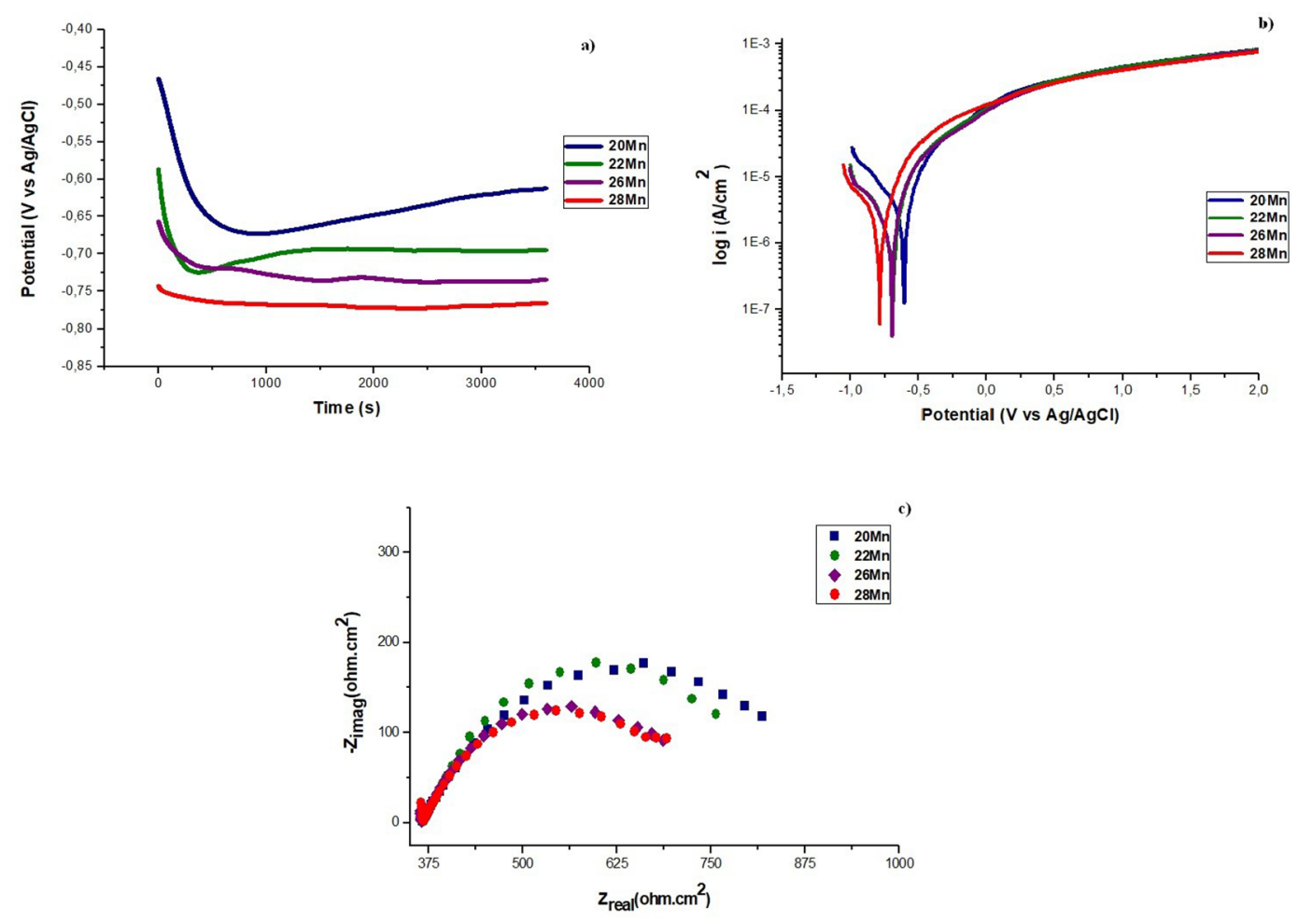

Figure 10. OCP (a) and linear polarization (b) curves of high manganese steels in aqueous solution of $0.1 \mathrm{M}$ de $\mathrm{NaCl}$. Source: author

In the linear polarization curves, it is observed a similar behavior in all steels. The curve of the $28 \%$ manganese steel is located at more negative potentials compared to other steels. The $22 \%$ and $26 \%$ manganese steels had equal behavior and a small difference in corrosion potential. The curve of the $20 \%$ manganese steel shows a more noble behavior. By the anodic branch of the polarization curve, it is observed that the process is governed by the transfer of charge, therefore, a generalized corrosion process will occur $^{14}$. The cathodic branch of the curves of these steels suggests that the reaction is controlled by diffusion, which implies the reduction of oxygen reaction ${ }^{15}$. Again, there are results showing a relationship between the decrease in corrosion resistance and the increase in the manganese content in steels. Park et al. ${ }^{16}$, they suggest that manganese has low stability, produces unstable layers that do not provide protection, and this element has preferential dissolution at the oxide/electrolyte interface.

The Pourbaix diagrams are another important tool to understand the phenomena that happened between the steel and the solution. Knowing the $\mathrm{pH}$ of the solution and the powers measured in the polarization study, it is possible to predict the behavior of the main elements that make up these steels. The $\mathrm{pH}$ of the $0.1 \mathrm{M} \mathrm{NaCl}$ solution was measured before and after the assays, resulting in values close to $\mathrm{pH} 7$.

In Figure 11, we observe the Pourbaix diagrams of the $\mathrm{Fe}, \mathrm{Mn}, \mathrm{Si}$ and $\mathrm{Al}$ elements. With a blue line that fixes the
$\mathrm{pH}$ of the solution, it is possible to appreciate the stability areas of the elements as they change the potentials obtained in the linear polarization tests. The iron diagram shows that, from the initial (most negative) potential used on the test up to the value of $0.05 \mathrm{~V}$, this element tends to form $\mathrm{FeOH}$, and with potentials higher than this value, iron forms the oxide $\mathrm{Fe}_{2} \mathrm{O}_{3}$. With manganese, it was found that, in potentials lower than $0.7 \mathrm{~V}$, it has the affinity to remain as $\mathrm{Mn}^{+2}$ ion, and in higher powers it has the tendency to form the $\mathrm{MnO}_{2}$ and $\mathrm{MnO}_{4}^{-}$(potentials above $0.9 \mathrm{~V}$ ). The silicon and aluminum diagrams show that they maintain the same phases from the beginning to the end of the test: $\mathrm{H}_{4} \mathrm{SiO}_{4}$ and $\mathrm{Al}_{2} \mathrm{O}_{3}$, respectively. This helps to understand that the low corrosion resistance of high manganese steels, and that the elements affinities make up these steels in reacting with the solution and leaving the metal matrix. An example of this is the great effect that manganese has in passing as ion in the solution instead of forming a protective oxide ${ }^{17,18}$.

\subsection{Characterization of corrosion products}

After the polarization tests, the corrosion products were analyzed with the help of SEM, EDS and Raman. In Figure 12, there are images obtained by SEM of the $20 \%$ manganese steel samples; magnifications of a) $500 \times$ and b) $1000 \times$ are observed. One can see a cracked layer of corrosion products that does not provide protection and that allows the contact between the solution and the blank metal, allowing 

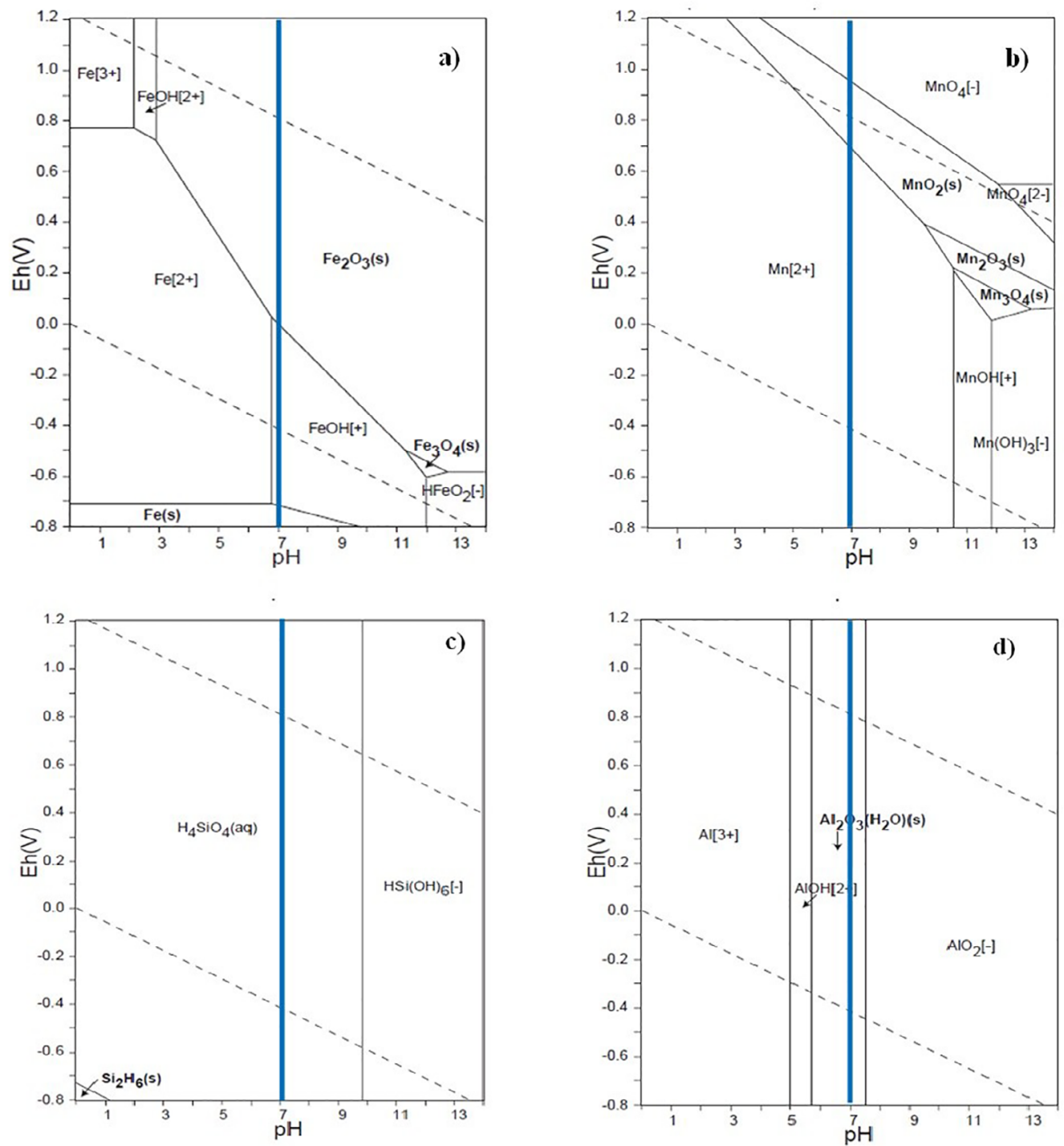

Figure 11. Pourbaix diagrams of Fe, Mn, Si and Al elements. Source: Takeno, $2005^{19}$.

the elements to pass as ions directly to the electrolyte ${ }^{9}$.It is also possible to observe how the lamellae of corrosion products are easily removed, implying their dissolution. Table 2 shows the EDS results of the $20 \%$ manganese steel corrosion products. $\mathrm{Fe}, \mathrm{Mn}, \mathrm{Al}, \mathrm{Si}, \mathrm{Cr}$ and $\mathrm{O}$ elements were found at the point indicated in figure 12, a); the amounts of these elements suggest that the layer is composed mainly of iron, manganese and aluminum oxides. Although the manganese has high affinity to pass as ion in the solution, the smaller amount of this element, compared to other steels, was important to improve the resistance to corrosion, as well as the small amounts of aluminum, silicon and chromium found, which influences the stabilization of the oxides ${ }^{9,20}$.

Figure 13 shows SEM images of the $22 \%$ manganese steel after the polarization test, with magnification of a) $500 \times$ and b) $1000 \times$, where there is a cracked layer of corrosion products on the sample surface that allows the blank metal to be exposed to the electrolytic solution"; this happens in the same way as in the $20 \%$ manganese steel, where parts of the layer are easily removed by the electrolyte effect ${ }^{21}$. Table 3 shows the results of the EDS measurement of the corrosion products of $22 \%$ manganese steel. $\mathrm{Fe}, \mathrm{Mn}, \mathrm{Al}, \mathrm{Si}, \mathrm{Cr}$ and $\mathrm{O}$ contents were found at the point indicated in figure 13 a). According to the analysis of the results, it is possible to recognize that the corrosion products are composed mainly of iron, manganese and oxygen, which indicates the presence of oxides of these elements. The aluminum, chromium and silicon elements were also obtained in low quantities, and this is due to the lower content of these elements in the steel composition. It can be observed that the decrease in the levels of chromium, aluminum and silicon, and especially the increase of manganese, influenced the lower corrosion resistance of this steel compared to the $20 \%$ manganese steel, as found by Reza et al. ${ }^{22}$. 

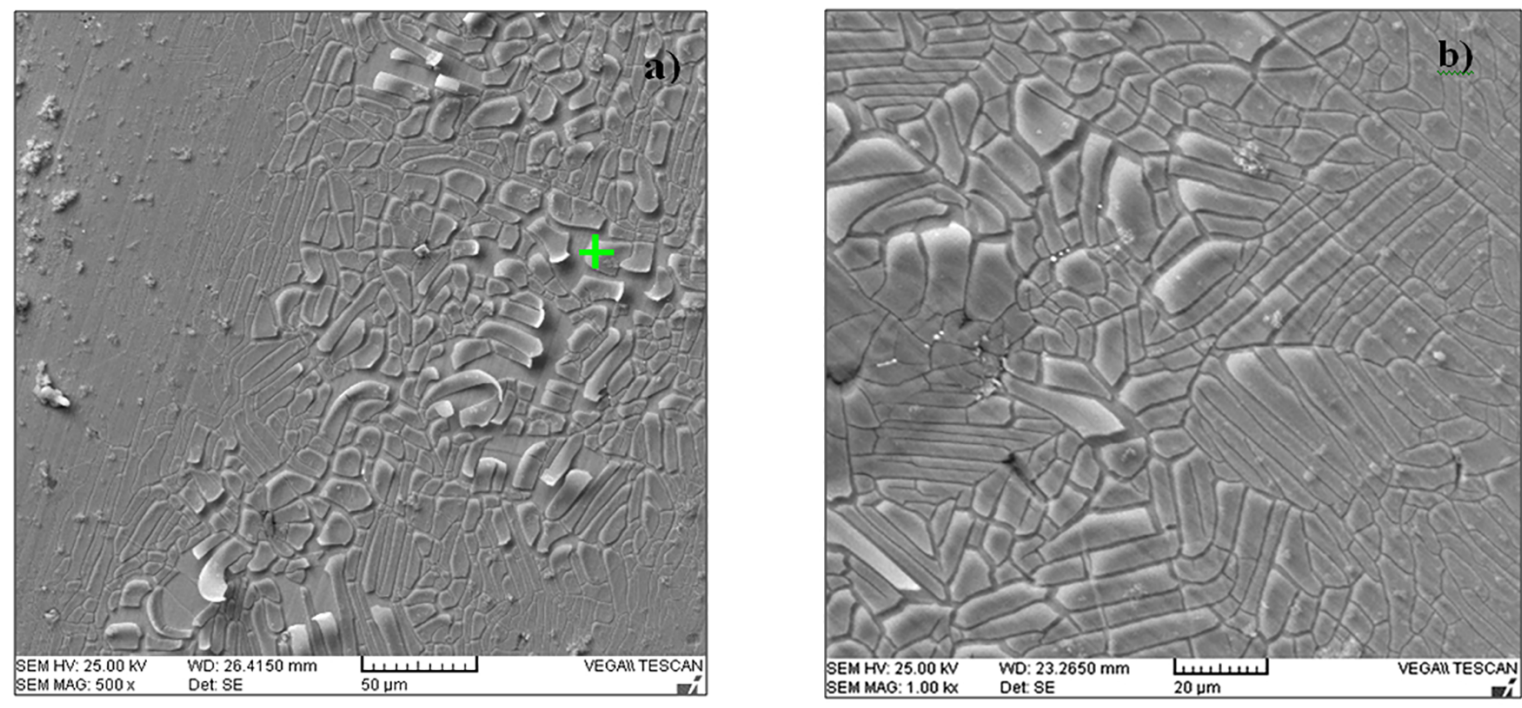

Figure 12. SEM of the $20 \%$ manganese steel corrosion products in aqueous solution $0.1 \mathrm{M} \mathrm{NaCl}$. Source: author

Table 2. Quantification of the elements in the corrosion products of the $20 \%$ manganese steel in solution $0.1 \mathrm{M}$ of $\mathrm{NaCl}$ made by EDS. Source: author

\begin{tabular}{lcccccc}
\hline \multicolumn{1}{l}{ Acquisition Spectrum: } & \multicolumn{1}{l}{} \\
\hline El & AN & Series & Unn. (wt.\%) & C Norm. (wt.\%) & C Atom. (at.\%) & C Erro (\%) \\
\hline $\mathrm{O}$ & 8 & K - series & 17,22 & 17,04 & 37,80 & 4,6 \\
$\mathrm{Al}$ & 13 & $\mathrm{~K}$ - series & 10,21 & 10,10 & 13,29 & 0,6 \\
$\mathrm{Si}$ & 14 & $\mathrm{~K}$ - series & 3,87 & 3,83 & 4,84 & 0,3 \\
$\mathrm{Cr}$ & 24 & K - series & 1,23 & 1,21 & 0,83 & 0,2 \\
$\mathrm{Mn}$ & 25 & K - series & 14,82 & 14,66 & 9,47 & 0,7 \\
$\mathrm{Fe}$ & 26 & K - series & 53,72 & 53,16 & 33,78 & 1,6 \\
Total & & 101,05 & 100,00 & 100,00 & \\
\hline
\end{tabular}
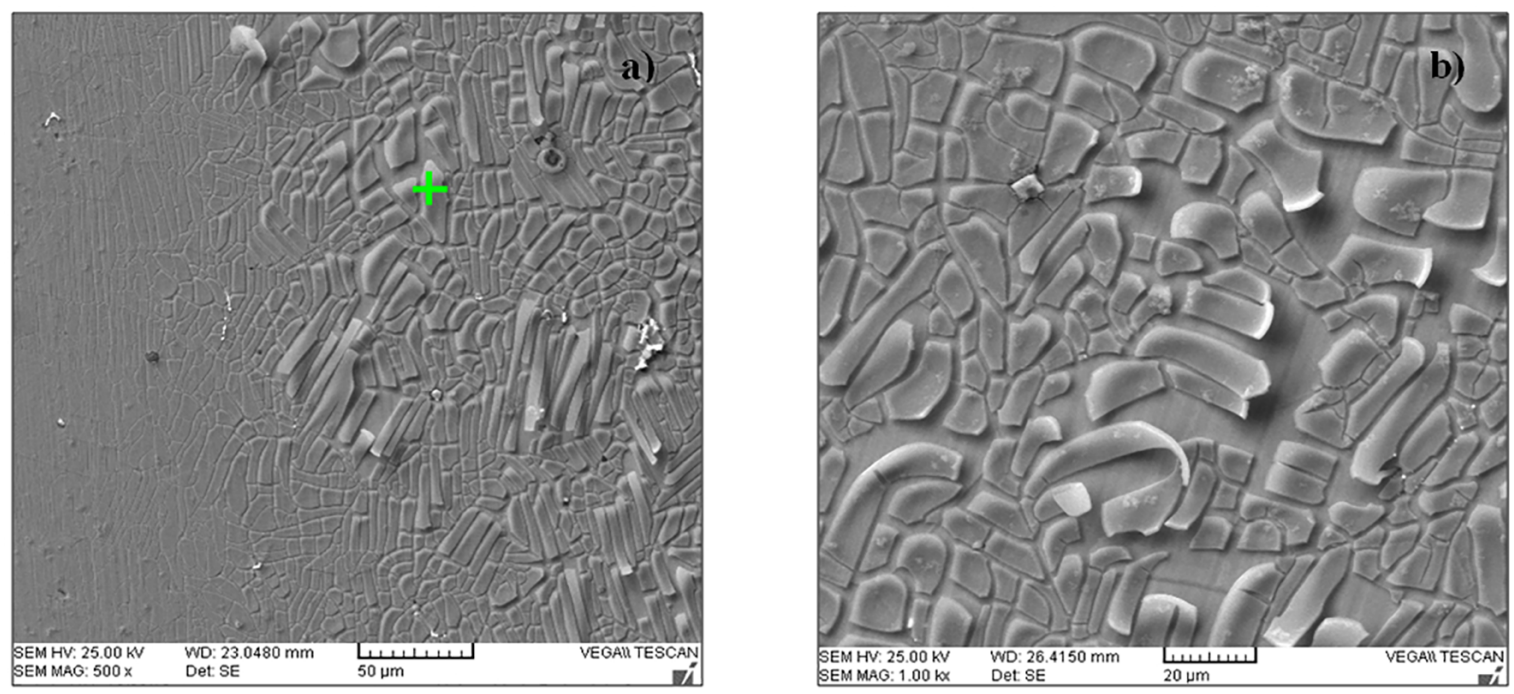

Figure 13. SEM of the $22 \%$ manganese steel corrosion products in aqueous solution $0.1 \mathrm{M} \mathrm{NaCl}$. Source: author 
Table 3. Quantification of the elements in the $22 \%$ manganese steel corrosion products in solution $0.1 \mathrm{M}$ of $\mathrm{NaCl}$ made by EDS. Source: author.

\begin{tabular}{|c|c|c|c|c|c|c|}
\hline \multicolumn{7}{|c|}{ Acquisition Spectrum: } \\
\hline EI & AN & Series & Unn. (wt.\%) & C Norm. (wt.\%) & C Atom. (at.\%) & C Erro (\%) \\
\hline $\mathrm{O}$ & 8 & $\mathrm{~K}$ - series & 18,98 & 19,61 & 41,63 & 4,7 \\
\hline $\mathrm{Al}$ & 13 & $\mathrm{~K}$ - series & 9,81 & 9,82 & 10,03 & 0,7 \\
\hline $\mathrm{Si}$ & 14 & $\mathrm{~K}$ - series & 3,05 & 3,19 & 4,08 & 0,2 \\
\hline $\mathrm{Cr}$ & 24 & $\mathrm{~K}$ - series & 1,01 & 1,06 & 0,75 & 0,2 \\
\hline $\mathrm{Mn}$ & 25 & $\mathrm{~K}$ - series & 16,41 & 16,92 & 10,25 & 0,6 \\
\hline $\mathrm{Fe}$ & 26 & $\mathrm{~K}$ - series & 51,74 & 49,40 & 33,26 & 1,3 \\
\hline Total & 101,00 & 100,00 & 100,00 & & & \\
\hline
\end{tabular}

Figure 14 shows SEM images of the $26 \%$ manganese steel after the polarization test are observed, with magnification of a) $500 \times$ and b) $1000 \times$. It is possible to see corrosion products that do not completely cover the surface of the sample; it is also possible to detail the presence of porosity and sanding marks on the exposed surface of the sample. In this steel, the lamellae covering the $20 \%$ and $22 \%$ manganese steels were not found. It is also noteworthy that, after the polarization test, the $\mathrm{NaCl}$ solution turned orange, which indicates the dissolution of the steel ${ }^{21}$. Table 4 shows the results of EDS measurement of the $26 \%$ manganese steel corrosion products, where $\mathrm{Fe}, \mathrm{Mn}, \mathrm{Al}, \mathrm{Si}, \mathrm{Cr}$ and $\mathrm{O}$ contents were found at the point indicated in figure 14 a). From the quantities, it can be stated that the corrosion products are mainly iron and manganese oxides. Silicon, chromium and aluminum were also found in quantities well below those of the 20 and $22 \%$ manganese steels, which are explained by the decrease of these elements in the chemical composition of this steel. The decrease of the alloying elements has an impact on the stability of the oxides formed, which, together with the increase of manganese in the steel composition, results in a higher output of $\mathrm{Mn}^{+2}$ ions from the metal matrix, reducing its corrosion resistance ${ }^{15}$.

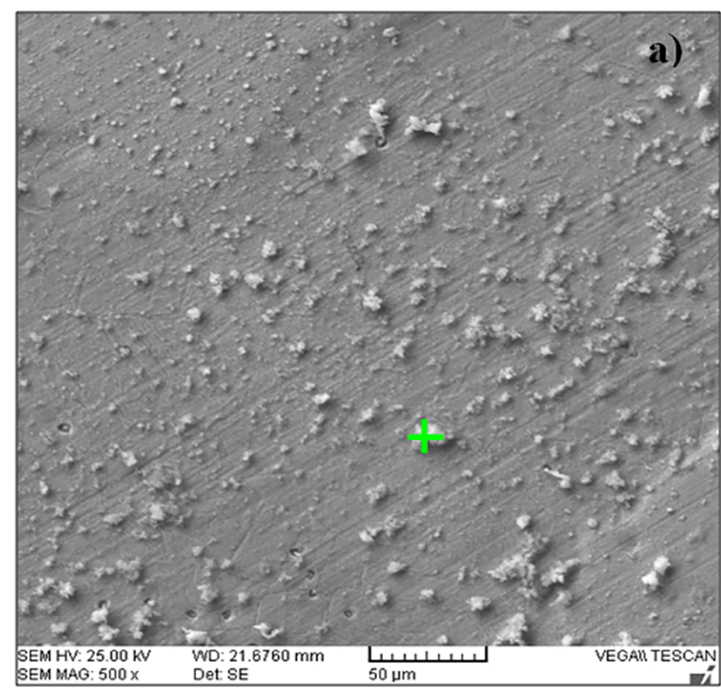

As in previous steels, in Figure 15 it is possible to see SEM images of the $28 \%$ manganese steel, with magnification of a) $500 \times$ and b) $1000 \times$; there are large amounts of corrosion products that appear to create pores when they leave the steel surface, as well as large craters along the observed region. All this is indicative of high dissolution of the material, that was corroborated by the reddish coloration of the solution after the test. These products are known in the literature as Green Rust - products that leave the steel surface in solutions containing chlorides 5 . Table 5 shows the results of EDS measurement of the $28 \%$ manganese steel corrosion products, where $\mathrm{Fe}, \mathrm{Mn}, \mathrm{Si}, \mathrm{Al}$ and $\mathrm{O}$ are found at the point indicated in figure $15 \mathrm{a}$ ). From the quantities found, it is possible to say that the corrosion products are mainly iron and manganese oxides. In this steel no chromium was found, and smaller amounts of silicon and aluminum confirm the lower stability of the corrosion products. The low performance purchased with the others used is due to the greater quantity of manganese available to leave the metal matrix and to pass as ion in the solution ${ }^{22,15}$

Figure 16 shows the Raman curves with the peaks of the species found in the corrosion products of the 5 steels studied. The results confirmed what Grajcar et $a{ }^{23}$ and

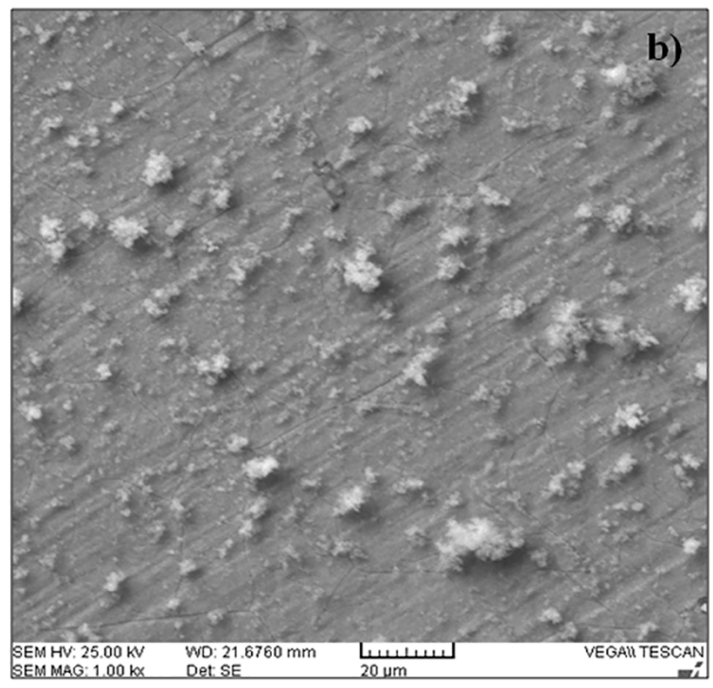

Figure 14. SEM of the $26 \%$ manganese steel corrosion products in aqueous solution $0.1 \mathrm{M} \mathrm{NaCl}$. Source: author 
Table 4. Quantification of the elements in the $26 \%$ manganese steel corrosion products in solution $0.1 \mathrm{M}$ of $\mathrm{NaCl}$ made by EDS. Source: author

\begin{tabular}{|c|c|c|c|c|c|c|}
\hline \multicolumn{7}{|c|}{ Acquisition Spectrum: } \\
\hline El & $\mathbf{A N}$ & Series & Unn. (wt.\%) & C Norm. (wt.\%) & C Atom. (at.\%) & C Erro (\%) \\
\hline $\mathrm{O}$ & 8 & $\mathrm{~K}$ - series & 25,38 & 25,55 & 54,34 & 7,9 \\
\hline $\mathrm{Al}$ & 13 & $\mathrm{~K}$ - series & 1,95 & 2,12 & 2,52 & 0,2 \\
\hline $\mathrm{Si}$ & 14 & $\mathrm{~K}$ - series & 2,49 & 2,7 & 3,09 & 0,2 \\
\hline $\mathrm{Cr}$ & 16 & $\mathrm{~K}$ - series & 0,78 & 0,85 & 0,52 & 0,1 \\
\hline $\mathrm{Mn}$ & 25 & $\mathrm{~K}$ - series & 18,21 & 19,09 & 7,48 & 0,6 \\
\hline $\mathrm{Fe}$ & 26 & $\mathrm{~K}$ - series & 51,30 & 50,69 & 32,04 & 1,6 \\
\hline Total & & & 100,11 & 100,00 & 100,00 & \\
\hline
\end{tabular}
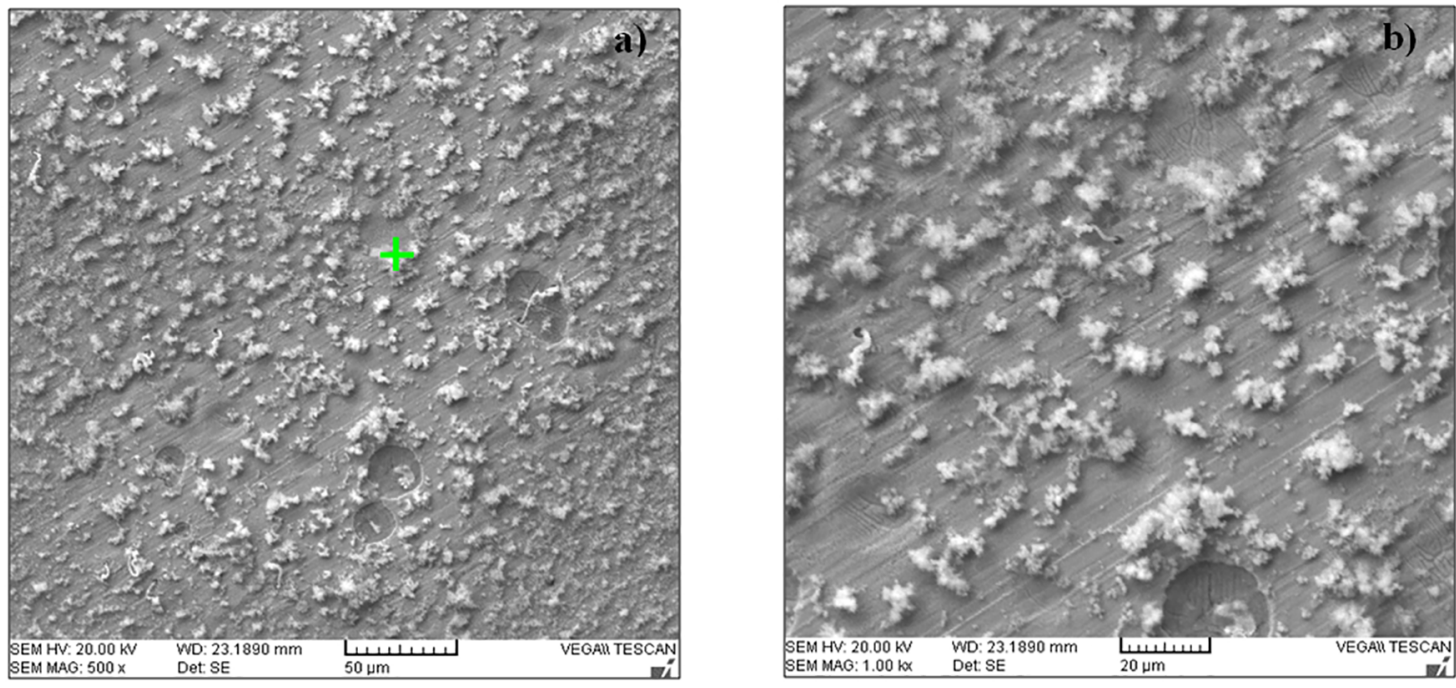

Figure 15. SEM of the $28 \%$ manganese steel corrosion products in aqueous solution $0.1 \mathrm{M} \mathrm{NaCl}$. Source: author

Table 5. Quantification of the elements in the $28 \%$ manganese steel corrosion products in solution $0.1 \mathrm{M}$ of $\mathrm{NaCl}$ made by EDS. Source: author.

\begin{tabular}{lcccccc}
\hline \multicolumn{1}{l}{ Acquisition Espectrum: } & \multicolumn{1}{l}{} \\
\hline El & AN & Series & Unn. (wt.\%) & C Norm. (wt.\%) & C Atom. (at.\%) & C Erro (\%) \\
\hline O & 8 & K - series & 30,95 & 30,90 & 59,07 & 5,7 \\
Al & 13 & K - series & 1,03 & 1,81 & 2,08 & 0,2 \\
Si & 14 & K - series & 2,04 & 1,93 & 1,99 & 0,2 \\
Mn & 25 & K - series & 20,15 & 20,31 & 9,53 & 0,7 \\
Fe & 26 & K - series & 47,73 & 45,05 & 27,33 & 1,6 \\
Total & & 102,10 & 100,00 & 100,00 & \\
\hline
\end{tabular}

Kannan et al. ${ }^{15}$ had mentioned: that the corrosion products of high manganese steels in aqueous solutions are mainly iron hydroxides known as Lepidocrite and Goethite. The compounds $\gamma$-FeOOH (lepidocrocite) and $\alpha-\mathrm{FeOOH}$ (goethite) were identified by the peaks $250 \mathrm{~cm}^{-1}, 528 \mathrm{~cm}^{-1}, 655 \mathrm{~cm}^{-1}$ and $249 \mathrm{~cm}^{-1}, 307 \mathrm{~cm}^{-1}, 554 \mathrm{~cm}^{-1}$, respectively ${ }^{24}$.

In the $20 \%$ and $22 \%$ manganese steels were found areas with presence of $\mathrm{Al}_{2} \mathrm{O}_{3}$, identified by the peaks $378 \mathrm{~cm}-1,418 \mathrm{~cm}-1,432 \mathrm{~cm}-1,648 \mathrm{~cm}-1$ and $755 \mathrm{~cm}-$ $1^{25}$. This compound was not found in the $26 \%$ and $28 \%$ manganese steels, due to the lower aluminum content in its chemical composition, as mentioned by Kannan et $a l .{ }^{15}$, that near a neutral $\mathrm{pH}$ high manganese steels with appreciable amounts of aluminum form films of oxides containing $\mathrm{Al}_{2} \mathrm{O}_{3}$.

\section{Conclusions}

Based on the experimental results obtained in the present study of characterization and comparison of corrosion resistance between high manganese steel models, the following can be concluded. 


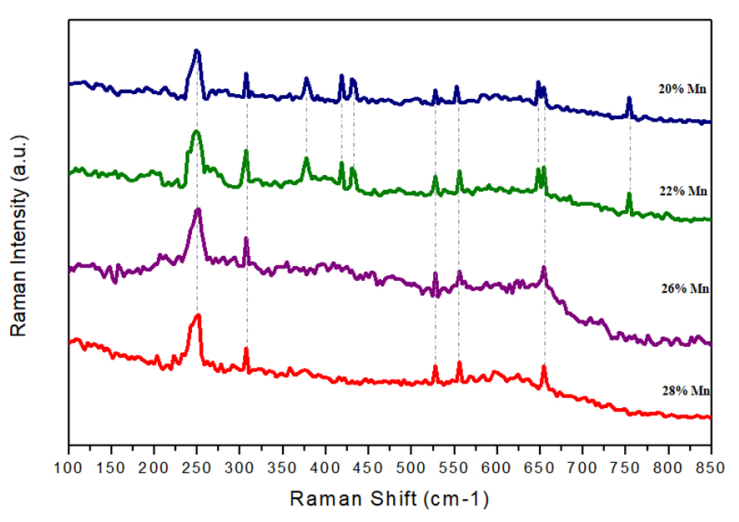

Figure 16. Raman spectrum of corrosion products of high manganese steels after the linear polarization test in solution $0.1 \mathrm{M}$ of $\mathrm{NaCl}$. Source: author

The temperature of the heat treatments chosen with the help of the thermodynamic diagrams made in Thermo-Calc ${ }^{\circledR}$ software, which were based on the chemical composition of the products, resulted in the desired austenitic microstructure. The diagrams were important to predict the possible present phases and to see how, as the manganese content in the steel increases, the temperature of transformation of austenite in ferrite decreases.

These steels present a completely austenitic microstructure with the formation of twins that help their hardening, being obstacles for the movement of dislocations, but the greater carbon content has more influence in the microhardness of these steels; in the inverse pole figures it has been shown that the grains do not have a defined crystallographic orientation.

It was also found that the increase of the manganese content is detrimental to the resistance to corrosion; the steel with less amount of this element had a more noble behavior. Elements such as chromium, silicon and aluminum help to stabilize the formed oxides, but the effect of the high tendency of dissolution of manganese is superior to the protection that these elements bring; this effect has been seen with the cracks in the layers of corrosion products that allow the electrolyte ions to reach the surface of the metal, accelerating the dissolution process.

\section{Acknowledgements}

This work has been supported by the Fundação Cearence de Apoio ao Desenvolvimento Cientifico e Tecnologico (FUNCAP).

\section{REFERENCES}

1. Choi JK, Lee SG, Park YH, Han IW, Morris Junior JW. High manganese austenitic steel for cryogenic applications. In: Proceedings of the $22^{\text {nd }}$ International Offshore and Polar Engineering Conference, by the International Society of Offshore and Polar Engineers (ISOP E); 2012 jun. 17-22; Rhodes, Greece: ISOPE; 2012.
2. Grässel O, Frommeyer G, Derder C, Hofmann H. Phase transformations and mechanical properties of Fe-Mn-Si-Al TRIP-Steels. Journal de Physique IV Colloque. 1997;7(C5):C5-383-C5-388.

3. Grässel O. High strength Fe-Mn-(Al, Si) TRIP/TWIP steels development - properties - application. International Journal of Plasticity. 2000;16(10-11):1391-1409.

4. Yuan, X, Chen L, Zhao Y, Di H, Zhu F. Influence of annealing temperature on mechanical properties and microstructures of a high manganese austenitic steel. Journal of Materials Processing Technology. 2014;217:278-85.

5. Hamada AS, Karjalainen LP, El-zeky MA. Effect of anodic passivation on the corrosion behaviour of $\mathrm{Fe}-\mathrm{Mn}$-Al steels in $3.5 \% \mathrm{NaCl}$. In: Passivation of metals and semiconductors, and properties of thin oxide layers. Proceedings of the 9th International Symposium Elsevier B.V.; 2005 jun 27 - jul 1; Paris, France: $9^{\text {th }}$ International Symposium; 2006. p. 77-82.

6. Zhang YS, Zhu XM, Liu M, Che RX. Effects of the anodic passivation on the constitution, stability and resistance to corrosion of passive film formed on an Fe-24Mn-4Al-5Cr alloy. Applied Surface Science. 2004;222(1-4):89-101.

7. Geels K, Fowler DB, Kopp WU, Rückert M. Metallographic and materialographic specimen preparation, light microscopy, image analysis and hardness testing, ASTM MNL 46. West Conshohocken, USA: ASTM International; 2007.

8. ASTM - American Society for Testing and Materials. E92 Standard test methods for Vickers hardness and Knoop hardness of metallic materials. West Conshohocken, USA: ASTM; 2017.

9. Opiela M, Grajcar A, Krukiewicz W. Corrosion behaviour of Fe-Mn-Si-Al austenitic steel in chloride solution. Journal of Achievements in Materials and Manufacturing Engineering. 2009;33(2):159-65.

10. Schumann VH. Martensitische Umwandlung in austenitischen Mangan-Kohlenstoff-Stählen. Neue Hütte. 1972;17:605-9.

11. Zambrano OA, Valdés J, Aguilar Y, Coronado JJ, Rodriguez SA, Logé RE. Hot deformation of a Fe-Mn-Al-C steel susceptible of K-carbide precipitation. Materials Science \& Engineering: A. 2017;(689):269-85.

12. Kim J, Cooman BC. Stacking fault energy and deformation mechanisms in Fe-xMn-0.6C-yAl TWIP steel. Materials Science \& Engineering: A. 2016;676:216-31.

13. Hamada AS, Karjalainen LP. Corrosion behaviour of high-Mn TWIP steels with electroless Ni-P coating. The Open Corrosion Journal. 2010;3(1):1-6.

14. Aperador WAR, Bautista JH, Betancurt JD. Evaluation of erosion-corrosion resistance in Fe-Mn-Al austenitic steels. Materials Research. 2013;16(2):447-52.

15. Kannan MB, Raman RKS, Khoddam S. Comparative studies on the corrosion properties of a Fe-Mn-Al-Si steel and an interstitial-free steel. Corrosion Science. 2008;50(10):2879-84.

16. Park JH, Seo HS, Kim KY, Kim SJ. The effect of Cr on the electrochemical corrosion of high Mn steel in a sweet environment. Journal of the Electrochemical Society. 2016;163(13):C791-C797.

17. Zhang YS, Zhu XM. Electrochemical polarization and passive film analysis of austenitic Fe-Mn-Al steels in aqueous solutions. Corrosion Science. 1999;41(9):1817-33. 
18. Lasek S, Mazancová E. Influence of thermal treatment on structure and corrosion properties of high manganese triplex steels. Metalurgija. 2012;52(4):441-4.

19. Takeno N. Atlas of Eh-pH diagrams - Intercomparison of thermodynamic databases. Geological survey of Japan open file report no. 419. Japan: National Institute of Advanced Industrial Science and Technology, Research Center for Deep Geological Environments; 2005.

20. Reza G, Gholami H, Gholam RZ, Zamani D, Saboktakin M, Monajati H. Study corrosion of high-Mn steels with Mo in 3.5\% $\mathrm{NaCl}$ solution. In: 2011 International Conference on Advanced Materials Engineering IPCSIT. Singapore: IACSIT Press; 2011. v. 15.

21. Grajcar A, Kolodziej S, Krukiewicz W. Corrosion resistance of high-manganese austenitic steels. International Scientific Journal Archives of Materials Science and Engineering. 2010;41(2):77-84.
22. Razavi GR, Monajati H. Corrosion behavior of TWIP steels in $3.5 \% \mathrm{NaCl}$ solution. Advanced Materials Research. 2012;457-458:334-37.

23. Grajcar A, Kciuk M, Topolska S, Płachcińska A. Microstructure and corrosion behavior of hot-deformed and cold-strained highMn steels. Journal of Materials Engineering and Performance. 2016;6(25):2245-54.

24. Maslar JE, Hurst WS, Bowers WJ, Hendricks JH, Aquino MI. In situ Raman spectroscopic investigation of aqueous iron corrosion at elevated temperatures and pressures. Journal of the Electrochemical Society. 2000;147(7):2532-42.

25. Krishnan R, Kesavamoorthy R, Dash S, Tyagi AK, Baldev R. Raman spectroscopic and photoluminescence investigations on laser surface modified $\alpha$-A12O3 coatings. Scripta Materialia. 2003;48(8):1099-104. 